\title{
The GRENE-TEA model intercomparison project (GTMIP): overview and experiment protocol for Stage 1
}

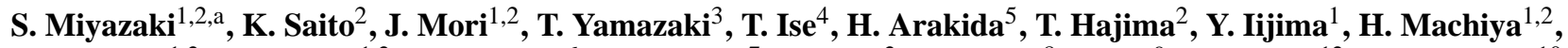 \\ T. Sueyoshi ${ }^{1,2}$, H. Yabuki ${ }^{1,2}$, E. J. Burke ${ }^{6}$, M. Hosaka ${ }^{7}$, K. Ichii ${ }^{2}$, H. Ikawa ${ }^{8}$, A. Ito ${ }^{9}$, A. Kotani ${ }^{12}$, Y. Matsuura ${ }^{10}$, \\ M. Niwano ${ }^{7}$, T. Nitta ${ }^{11}$, R. O'ishi ${ }^{1,11}$, T. Ohta ${ }^{12}$, H. Park ${ }^{2}$, T. Sasai ${ }^{13}$, A. Sato ${ }^{14}$, H. Sato ${ }^{2}$, A. Sugimoto ${ }^{15}$, R. Suzuki ${ }^{2}$, \\ K. Tanaka $^{2}$, S. Yamaguchi ${ }^{14}$, and K. Yoshimura ${ }^{11}$ \\ ${ }^{1}$ National Institute of Polar Research, Tachikawa, Japan \\ ${ }^{2}$ Japan Agency for Marine-Earth Science and Technology, Yokohama, Japan \\ ${ }^{3}$ Graduate School of Science, Tohoku University, Sendai, Japan \\ ${ }^{4}$ Field Science Education and Research Center, Kyoto University, Kyoto, Japan \\ ${ }^{5}$ Advanced Institute for Computational Science, RIKEN, Kobe, Japan \\ ${ }^{6}$ Met Office Hadley Centre, Exeter, UK \\ ${ }^{7}$ Meteorological Research Institute, Tsukuba, Japan \\ ${ }^{8}$ National Institute for Agro-Environmental Sciences, Tsukuba, Japan \\ ${ }^{9}$ National Institute for Environmental Studies, Tsukuba, Japan \\ ${ }^{10}$ Forestry and Forest products Research Institute, Tsukuba, Japan \\ ${ }^{11}$ Atmosphere and Ocean Research Institute, The University of Tokyo, Kashiwa, Japan \\ ${ }^{12}$ Graduate School of Bioagricultural Sciences, Nagoya University, Nagoya, Japan \\ ${ }^{13}$ Faculty of Life and Environmental Science, University of Tsukuba, Tsukuba, Japan \\ ${ }^{14}$ Snow and Ice Research Center, National Research Institute for Earth Science and Disaster Prevention, Nagaoka, Japan \\ ${ }^{15}$ Faculty of Environmental Earth Science, Hokkaido University, Sapporo, Japan \\ ${ }^{a}$ now at: Sonic Corporation, Tachikawa, Japan
}

Correspondence to: K. Saito (ksaito@jamstec.go.jp)

Received: 27 March 2015 - Published in Geosci. Model Dev. Discuss.: 29 April 2015

Revised: 13 August 2015 - Accepted: 17 August 2015 - Published: 9 September 2015

\begin{abstract}
As part of the terrestrial branch of the Japanfunded Arctic Climate Change Research Project (GRENETEA), which aims to clarify the role and function of the terrestrial Arctic in the climate system and assess the influence of its changes on a global scale, this model intercomparison project (GTMIP) is designed to (1) enhance communication and understanding between the modelling and field scientists and (2) assess the uncertainty and variations stemming from variability in model implementation/design and in model outputs using climatic and historical conditions in the Arctic terrestrial regions. This paper provides an overview of all GTMIP activity, and the experiment protocol of Stage 1, which is site simulations driven by statistically fitted data created using the GRENE-TEA site observations for the last 3 decades. The target metrics for the model evaluation cover
\end{abstract}

key processes in both physics and biogeochemistry, including energy budgets, snow, permafrost, phenology, and carbon budgets. Exemplary results for distributions of four metrics (annual mean latent heat flux, annual maximum snow depth, gross primary production, and net ecosystem production) and for seasonal transitions are provided to give an outlook of the planned analysis that will delineate the inter-dependence among the key processes and provide clues for improving model performance. 


\section{Introduction}

The pan-Arctic ecosystem is characterized by low mean temperatures, snow cover, and seasonal frozen ground or permafrost with a large carbon reservoir, covered by various biomes (plant types) ranging from deciduous and evergreen forests to tundra. The Arctic climate and ecosystem differ from the tropical and temperate counterparts primarily because it is a frozen world. Moreover, the terrestrial Arctic varies from area to area according to the location, glacial history, and climatic conditions. However, sites, networks, and opportunities for direct observations are still sparse relative to the warmer regions owing to physical and logistical limitations. To investigate the impact of climate change in this region, a number of studies using both analyses of observed data and numerical modelling have been carried out (e.g. Zhang et al., 2005; Brown and Robinson, 2011; Brutel-Vuilmet et al., 2013; Koven et al., 2011, 2013; Slater and Lawrence, 2013). Various numerical modelling schemes have been developed to treat physical and biogeochemical processes on and below the land surface. Some of these processes are site-specific or process-oriented, while others are implemented as components of atmosphere-ocean coupled global climate models (AOGCMs), or Earth system models (ESMs) to interact with the overlying atmosphere. Among these processes, snowpack, ground freezing/thawing, and carbon exchange are the most relevant and important processes in terrestrial process models (TPMs) for investigating the climate and ecosystem of the pan-Arctic region.

\subsection{GRENE Arctic project and GTMIP}

The GRENE-TEA model intercomparison project (GTMIP) was originally planned as part of the terrestrial research project of the GRENE Arctic Climate Change Research Project (GRENE-TEA) to achieve the following targets: (a) to pass possible improvements regarding physical and biogeochemical processes for Arctic terrestrial modelling (excluding glaciers and ice sheets) in the existing AOGCM terrestrial schemes for the AOGCM research community, and (b) to lay the foundations for the development of future-generation Arctic terrestrial models. The project, however, involves groups of researchers from different backgrounds/disciplines (e.g. physics/geophysics, glaciology, biogeochemistry, ecosystem, forestry) with a wide range of research methods (e.g. field observations, remote sensing, numerical modelling), target domains (e.g. northern Europe, Siberia, Alaska, northern Canada) and scales (from site-level to pan-Arctic). As is often the case, multidisciplinary opportunities were limited, initially creating a considerable challenge for the project (Fig. 1a). Communications between groups (e.g. modelling and field studies, physical and ecosystem disciplines, process-oriented and large-scale modelling), if any, were inconclusive and sporadic. Observational practices and procedures (e.g. variables to measure, equipment
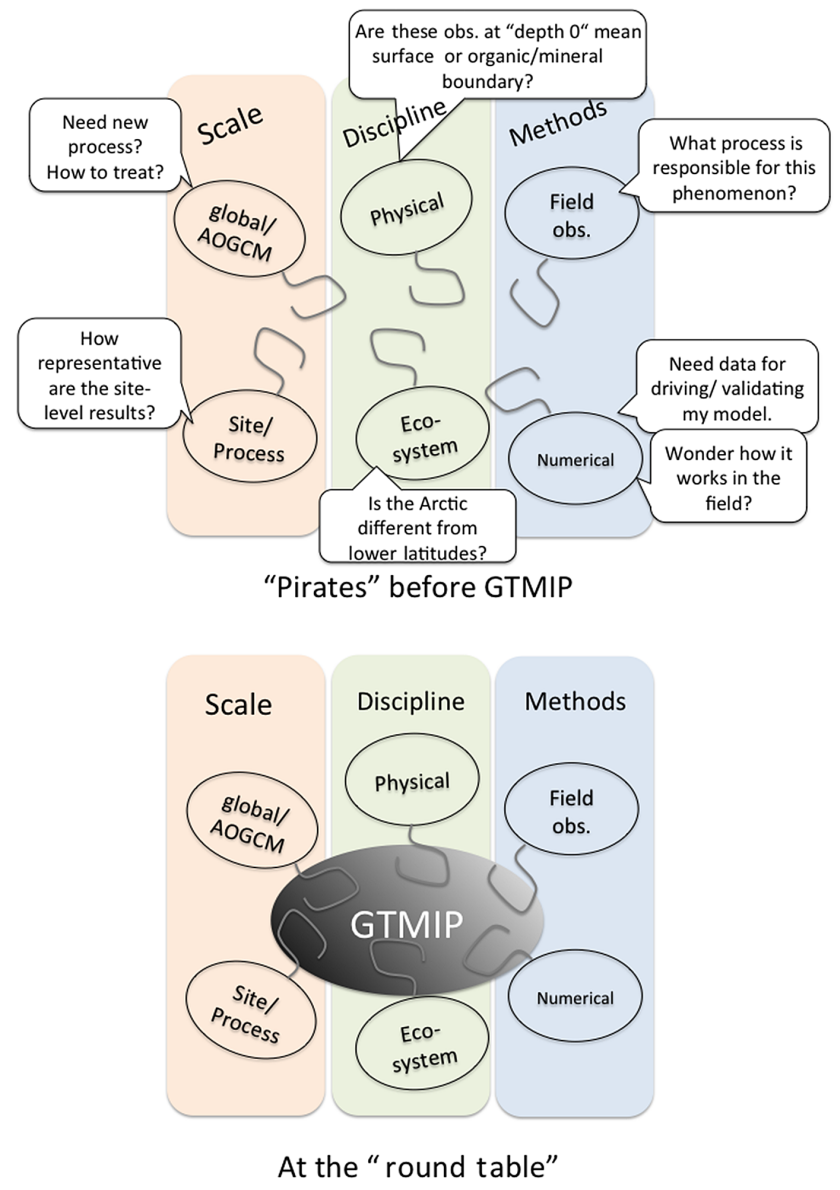

Figure 1. "Pirates of the Arctic" sit at the round table.

to use, standard zero depth for ground measurements) were different among groups and disciplines and lacked standardization. Although each individual group had the needs and intention to interact with other groups, the requisite collaboration could not be achieved. Opinions obtained in the early stages revealed hidden quests for possible collaborations for observational data for driving and/or validating data, use of numerical models to test empirical hypotheses gained at the field, interpretation of observed phenomena, and optimization of observation network strategies. As a result of this situation, the model intercomparison project was deliberately blueprinted to promote communication and understanding between modelling and empirical scientists, and among modellers: the GTMIP protocols and data sets are set to function as a hub for the groups involved in the project (Fig. 1b). It also aimed to enhance the standardization of observation practices among the GRENE-TEA observation sites and to form a tight collaboration between the field and modelling communities, laying a cornerstone for creating the driving data set (details of the Stage 1 driving data and their creation as a product of collaboration between modellers and field scientists are documented by Sueyoshi et al., 2015). 


\subsection{Model intercomparison for the terrestrial Arctic}

Since the 1990s, a number of model intercomparison projects (MIPs) have been carried out, focusing on the performance of TPMs, AOGCMs, and ESMs; examples include PILPS (Project for Intercomparison of Land-Surface Parameterization Schemes; Henderson-Sellers, 1993), SnowMIP (Snow Models Intercomparison Project; Etchevers et al., 2004; Essery et al., 2009), Potsdam NPP MIP (Potsdam Net Primary Production Model Intercomparison Project; Cramer et al., 1999), C4MIP (Coupled Climate-Carbon Cycle Model Intercomparison Project; Friedlingstein et al., 2006), CMIP5 (Coupled Model Intercomparison Project; Taylor et al., 2012), and MsTMIP (Multi-scale synthesis and Terrestrial Model Intercomparison Project; Huntzinger et al., 2013), to name a few.

For snow dynamics, SnowMIP2 showed a broad variety in the maximum snow accumulation values, particularly at warmer sites and in warmer winters, although the duration of snow cover was relatively well simulated (Essery et al., 2009). The same study also noted that the SnowMIP2 models tend to predict winter soil temperatures that are too low for cold sites and for sites with shallow snow, a discrepancy arguably caused by the remaining uncertainties in ecological and physical processes and the scarcity of winter process measurements for model development and testing in the boreal zone. The CMIP5 models simulated the snow cover extent for most of the Arctic region well, except for the southern realm of the seasonal snow cover area (BrutelVulmet et al., 2013). The poor performance of some of the TPMs in this region is due to an incorrect timing of the snow onset and possibly to an incorrect representation of the annual maximum snow cover fraction (Brutel-Vulmet et al., 2013). For ground freezing/thawing processes, Koven et al. (2013) showed the current status of the performance of AOGCMs for permafrost processes based on CMIP5 experiments. There was large disagreement among modelled soil temperatures, which may have been due to the representation of the thermal connection between the air and the land surface and, in particular, its mediation by snow in winter. Vertical profiles of the mean and amplitude of modelled soil temperatures showed large variations, some of which can be attributed to differences in the physical properties of the modelled soils and coupling between energy and water transfer. This appears to be particularly relevant for the representation of organic layers.

For the biogeochemical cycles, a number of studies based on MIPs have been carried out. The broad global distribution of net primary productivity (NPP) and the relationship of annual NPP to the major climatic variables coincide in most areas with differences among the 17 global terrestrial biogeochemical models that cannot be attributed to the fundamental modelling strategies (Cramer et al., 1999). The ESMs in CMIP5 use the climate and carbon cycle performance metrics, and they showed that the models correctly reproduced the main climatic variables controlling the spatial and temporal characteristics of the carbon cycle (Anav et al., 2013). However, several weaknesses were found in the modelling of the land carbon cycle: for example, the leaf area index is generally overestimated by models compared with remote sensing data (Anav et al., 2013); NPP and terrestrial carbon storage responses to $\mathrm{CO}_{2}$ increases greatly differ among models (Hajima et al., 2014); current ESMs display large variations for the estimated soil carbon amounts, in particular for northern high latitudinal regions, and lack the capability to represent the potential degradation of frozen carbon in permafrost regions (Todd-Brown et al., 2014). The future projection by ESMs suggests that the carbon sink characteristic will increase in northern high latitudes, although there are some uncertainties such as nutrient limitations in $\mathrm{CO}_{2}$ fertilization, the effect of soil moisture on decomposition rates, and mechanistic representations of permafrost (Qian et al., 2010; Ahlstrom et al., 2012; Arora et al., 2013). It should be noted that the reference observation data used for these evaluations are prone to uncertainties due to random and bias errors in the measurements themselves, sampling errors, and analysis error, especially for biogeochemical variables such as land gross primary productivity (GPP) (e.g. Anav et al., 2013; Piao et al., 2013). Based on the outcomes of these MIPs, TPMs have improved their performances.

At scales from a continental level (including those mentioned above) to site level (model-observation comparisons; e.g. Zaehle et al., 2014), different MIPs have also been conducted and generally study physical or ecosystem processes separately. PILPS (Henderson-Sellers et al., 1993) and a series of snow MIPs (Etchevers et al., 2004; Essery et al., 2009) are well-known MIPs for physical processes, targeting hydrology and snow dynamics. Recently, a MIP for tundra sites has been conducted but its focus is limited to soil thermal dynamics (Ekici et al., 2015). In turn, ecosystem MIPs on continental scales have two predecessors: the North American Carbon Program site synthesis (Schwalm et al., 2010) and CarboEastAsia-MIP (Ichii et al., 2013). Although both MIPs employ multiple terrestrial biosphere models to different eddy-covariance measurement sites (Schwalm et al., 2010, with 22 models for 44 sites in North America; Ichii et al., 2013, with 8 models for 24 sites in Asia), boreal and Arctic sites were not the major targets. In other studies targeting specific eco-climatic regions, the Arctic was again not the main domain: Jung et al. (2007) assessed GPPs for Europe and Ichii et al. (2010) for Japan. Rawlins et al. (2015) assessed carbon budget differences among several GCMcompatible models in northern Eurasia, with little examination of the physical processes. In other regions than the Arctic, there have been cross-sectional evaluations of physical and ecosystem processes, such as Morales et al. (2005), evaluating carbon and water fluxes in Europe, and de Gonçalves et al. (2013), the LBA-Data Model Intercomparison Project (LBA-DMIP), analysing water and carbon fluxes in the Amazon. 


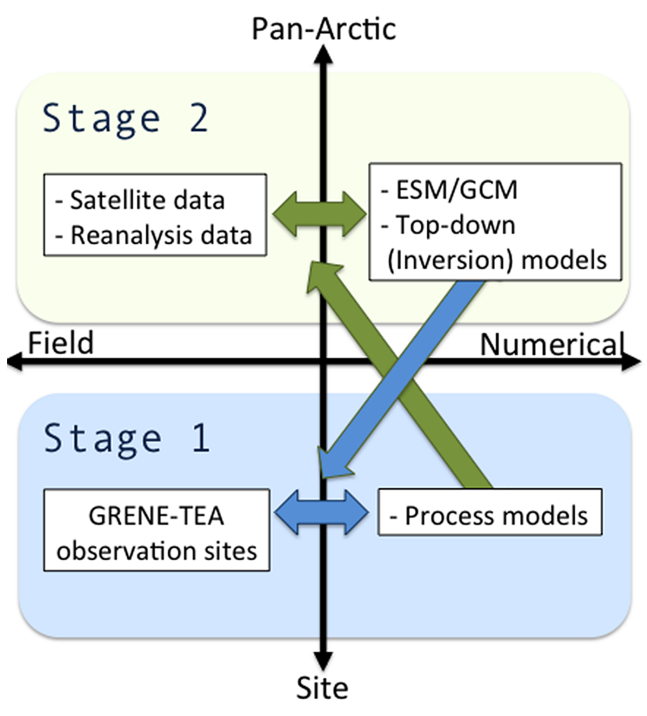

Figure 2. Schematic diagram for stages 1 and 2 of GTMIP.

The GTMIP consists of two stages (Fig. 2): one dimensional, historical GRENE-TEA site evaluations for examining the model's behaviour and its uncertainty (Stage 1); and circumpolar evaluations using projected climate change data from GCM outputs (Stage 2). Hereafter, we describe the Stage 1 protocol. This stage aims to evaluate the physical and biogeochemical TPMs through 3-decade site simulations driven and validated by the GRENE-TEA site-derived data. It calls for broader participation in the activity from a wider community to assure robust assessments for model-derived uncertainty and to efficiently investigate the terrestrial system response to climate variability considering the diversity of the pan-Arctic sites. Thus, the scope and geographical domain of GTMIP Stage 1 is unique in its target of the Arctic region, including both taiga and tundra, and in its evaluations of the behaviour of the energy-snow-soil-vegetation subsystem, employing a wide range of models from physical land surface schemes to terrestrial ecosystems.

\section{Experiment design}

\subsection{Targeted processes}

In GTMIP, a variety of models ranging from specific models that focus on snowpack formation processes to highly complex DGVMs (dynamic global vegetation models) are expected to participate. The following five categories (from "a" to "e") set the unit for the key processes to assess the performance of the existing TPMs in the pan-Arctic region, to evaluate the variations among the models and the mechanisms behind their strengths and weaknesses, and to obtain information and guidance to improve the next generation of TPMs. The five categories are (a) exchange of energy and water between atmosphere and land, (b) the

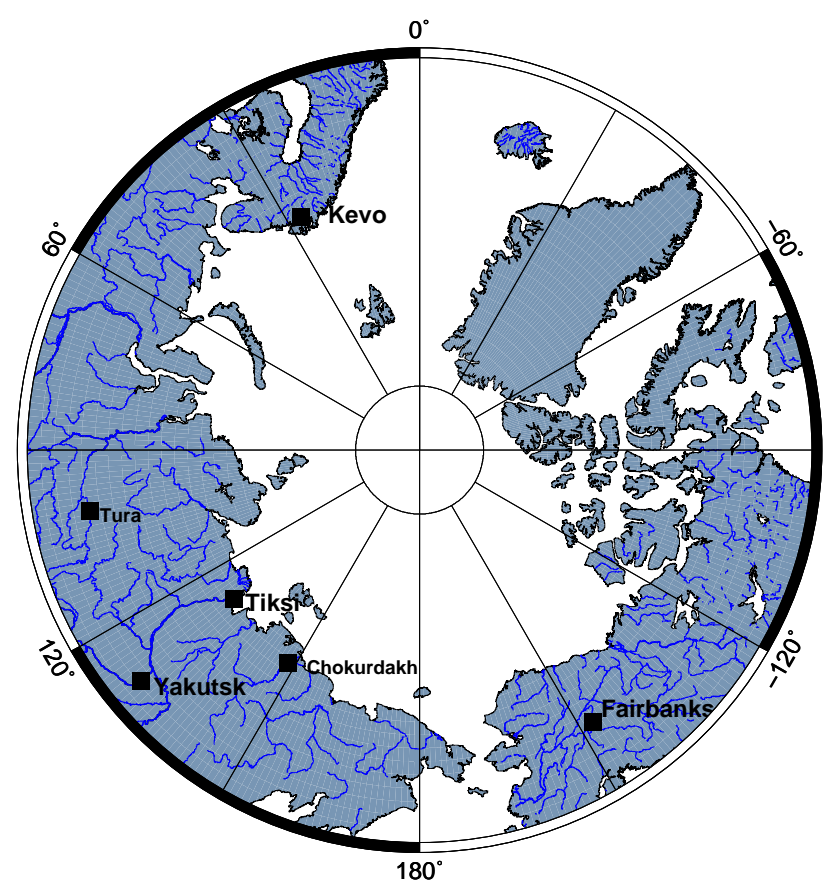

Figure 3. Location map of the GRENE-TEA sites.

snowpack, (c) phenology, (d) ground freezing/thawing and the active layer, and (e) the carbon budget. The categories cover the essential processes that make the pan-Arctic region unique compared with other regions: seasonal changes in both physical and biogeochemical processes and the associated strong climate feedback, which are characterized by liquid-ice phase changes, the subsequent ecosystem response, and their interactions.

The scientific questions at the Stage 1 are the following. How well do the TPMs reproduce target metrics (examples are shown in column B in Table 1) in terms of agreement with observations? How do the reproductions vary among the models? If the reproductions are good or poor in some models, which processes in the TPMs are responsible and why?

\subsection{Driving data sets and model parameters}

The target period for Stage 1 was set from 1980 to 2013 to provide at least 30 years of data, the minimum requirement for climatological analyses. The period is also favourable in terms of the accuracy and coherence of the relevant largescale climate data thanks to the fully fledged operation of various satellite observations (e.g. Dee et al., 2011). We are providing the following driving data for Stage 1: surface air temperature, precipitation, specific humidity, air pressure, wind speed, incident short-wave and long-wave radiation.

For this stage (site simulations), forcing and validation data have been prepared, taking maximum advantage of the observation data from GRENE-TEA sites in operation (Fair- 
Table 1. The key process categories and target processes.

\begin{tabular}{ll}
\hline A: key processes categories & B: target processes and metrics \\
\hline Energy and water budget & $\begin{array}{l}\text { Partition of energy and water at surface, canopy, and } \\
\text { subsurface, albedo } \\
\text { Snow water equivalent, snow density, snow cover dura- } \\
\text { tion (length and dates) } \\
\text { depth/snow water equivalent) } \\
\text { Phenology }\end{array}$ \\
Annual maximum leaf area index, growing season \\
(length and dates)
\end{tabular}

banks (FB) in Alaska; Tiksi (TK), Yakutsk (YK), Chokurdakh (CH), and Tura (TR) in Russia; and Kevo (KV) in Finland, shown in Fig. 3), to evaluate the inter-model and intersite variations for 1980-2013. These sites, the latitudes of which vary from 62 to $71^{\circ} \mathrm{N}$, have different characteristics in terms of climate (e.g. air temperature, precipitation), snow (e.g. type, amount and accumulation period), vegetation, and frozen ground conditions (Sueyoshi et al., 2015), providing a good representation of the diversity of the terrestrial Arctic. The annual air temperature and precipitation at the six sites ranges from -13.5 to $-1.6^{\circ} \mathrm{C}$ and from 188 to $415 \mathrm{~mm}$, respectively. Four sites (FB, KV, YK, and TR) are in the boreal forest, while TK is in tundra and $\mathrm{CH}$ in the tundra-forest transition zone. Most of the sites are located in the permafrost zone with an active layer ranging from 0.4 to $1.2 \mathrm{~m}$, except for the KV site, which is seasonally frozen.

Because of the severe conditions for maintaining monitoring sites in the Arctic region, continuous observation data over years are scarce, which makes it very difficult to create ready-to-drive data directly from observations (e.g. owing to missing values, discontinuity of measurement periods, outliers). To overcome this problem, we first constructed the backbone of the continuous forcing data (called "level 0" or L0; Saito et al., 2014a) from climate reanalysis products to avoid the issues of limited coverage and/or missing data, or the lack of consistency inherent in observational data, using the bias-corrected monthly Climate Research Unit (CRU) for the temperature data set (Harris et al., 2014) and the Global Precipitation Climatology Project (GPCP) for the precipitation data set (Adler et al., 2003) at the respective nearest grid to the sites. The European Centre for Medium-range Weather Forecasts ReAnalysis (ERA)-interim reanalysis data (Dee et al., 2011) were chosen from four products (National Centers for Environmental Prediction/National Center for Atmospheric Research (NCEP/NCAR), NCEP-Department of Energy (DOE), Japanese Reanalysis (JRA)-55, and ERAinterim) because they showed the smallest bias relative to the monthly CRU and GPCP in terms of $2 \mathrm{~m}$ air temperature and precipitation in the pan-Arctic region (north of $60^{\circ} \mathrm{N}$ ).
Assimilation of the observed data was then applied to reflect local characteristics and to derive the primary driving data, "level 1" data (L1; Saito et al., 2014b) and, in addition, the level 1 hybrid data $(\mathrm{L} 1 \mathrm{H})$ by replacing data with observed data when available. The L1 data set was provided for four sites (FB, KV, TK, and YK) owing to the availability of the observed data for validations. For the creation of the site-specific data, collaboration with the field scientists who are in charge of the observation sites and know the circumstances of the data obtained was critical. Further details on the creation of the LO and L1 data sets, and their basic statistics, are described in Sueyoshi et al. (2015).

As the warming trend is becoming visible, in particular for northern high-latitude regions (IPCC, 2013), the 20-year detrended meteorological driving data set is provided for spin up, allowing biogeochemical models to set up initial soil carbon conditions without the warming trends and/or ENSO (El Niño-Southern Oscillation). This data set is based on the L1 data for the period of 1980-1999 (Saito et al., 2015). The monthly values of the fraction of photosynthetically active radiation (fPAR) and leaf area index (LAI) data sets at GRENE-TEA sites, created based on Moderate Resolution Imaging Spectroradiometer (MODIS) satellite data (MOD15A2, MYD15A2), are also provided where required (Saito et al., 2014c). These driving data sets are provided in the ASCII fixed-length record files and are available through the Arctic Data Archive System (ADS; https://ads.nipr.ac.jp/ gtmip/gtmip.html), along with the simulation protocol.

The site description, including locations, dominant vegetation types, soil, climate, fPAR, LAI, data for model validation, and references for observation data, is summarized in Table 2 .

\subsection{Model setup}

As already proposed in existing MIP studies (e.g. Ichii et al., 2010), we set Stage 1 to consist of two further substages: 1A and $1 \mathrm{~B}$. Substage $1 \mathrm{~A}$, which aims to evaluate the inter-model variations in baseline performance at each site, requested the 
Table 2. The location, dominant vegetation type, soil, climate, fraction of photosynthetically active radiation (fPAR), possible data for validation, and references for observed data for (a) Fairbanks, (b) Kevo, (c) Tiksi, (d) Yakutsk, (e) Chokurdakh, and (f) Tura.

\begin{tabular}{ll}
\hline (a) Fairbanks (Poker Flat Research Range), Alaska, USA \\
\hline Location & $65^{\circ} 07^{\prime} 24^{\prime \prime} \mathrm{N}, 147^{\circ} 29^{\prime} 15 .^{\prime \prime} \mathrm{W}$ \\
Altitude & $210 \mathrm{~m}$ \\
Dominant vegetation type & Black spruce forest \\
Soil & $0-14 \mathrm{~cm}$ layer: moss \\
& $14-25 \mathrm{~cm}$ : undecomposed organic layer \\
& $25-39 \mathrm{~cm}$ : decomposed organic layer \\
& $39 \mathrm{~cm}$ silt soil \\
& Active layer thickness: $43 \mathrm{~cm}$ in 2013 \\
& Mean annual air temperature: $-2.8^{\circ} \mathrm{C}(2011)$ \\
& Annual precipitation: $312 \mathrm{~mm}(2011)$ \\
Climate & fPAR: 0.03 (Jan), 0.05 (Feb), 0.05 (Mar), 0.13 (Apr), 0.39 (May), 0.69 (Jun), \\
& 0.69 (Jul), 0.69 (Aug), 0.43 (Sep), $0.23($ Oct), 0.06 (Nov), 0.00 (Dec) \\
fPAR and LAI* & LAI: 0.05 (Jan), 0.09 (Feb), 0.09 (Mar), 0.23 (Apr), 0.99 (May), 2.26 (Jun), \\
& 2.32 (Jul), 1.90 (Aug), 0.80 (Sep), $0.49($ Oct), 0.10 (Nov), 0.01 (Dec) \\
& Snow depth, ground temperature ( $-0.05,-0.1,-0.2,-0.4,-1.0$ m), soil moisture \\
& (-0.05, $-0.1,-0.2,-0.4 \mathrm{~m})$, leaf area index, albedo, fPAR (fraction of photo- \\
Data available for model validation & synthetically active radiation), upward short- and long-wave radiation, energy and \\
& carbon fluxes \\
& Nakai et al. (2013)
\end{tabular}

(b) Kevo (Kevo Research Station), Finland

\begin{tabular}{|c|c|}
\hline Location & $69^{\circ} 45^{\prime} 25^{\prime \prime} \mathrm{N}, 27^{\circ} 00^{\prime} 37^{\prime \prime} \mathrm{E}$ \\
\hline Altitude & $100 \mathrm{~m}$ \\
\hline Dominant vegetation type & Pine forest \\
\hline Soil & $\begin{array}{l}0-20 \mathrm{~cm} \text { : humus soil } \\
20-50 \mathrm{~cm} \text { : sandy silt }\end{array}$ \\
\hline Climate & $\begin{array}{l}\text { Mean annual air temperature: }-1.6^{\circ} \mathrm{C} \\
\text { Annual precipitation: } 415 \mathrm{~mm}\end{array}$ \\
\hline fPAR and $\mathrm{LAI}^{*}$ & $\begin{array}{l}\text { fPAR: } 0.03 \text { (Jan), } 0.06 \text { (Feb), } 0.08 \text { (Mar), } 0.11 \text { (Apr), } 0.51 \text { (May), } 0.56 \text { (Jun), } \\
0.69 \text { (Jul), } 0.76 \text { (Aug), 0.68 (Sep), } 0.45 \text { (Oct), } 0.10 \text { (Nov), } 0.02 \text { (Dec) } \\
\text { LAI: 0.05 (Jan), 0.10 (Feb), 0.14 (Mar), } 0.21 \text { (Apr), 1.13 (May), } 1.63 \text { (Jun), } \\
2.52 \text { (Jul), } 2.78 \text { (Aug), } 1.66 \text { (Sep), } 1.18 \text { (Oct), } 0.21 \text { (Nov), } 0.05 \text { (Dec) }\end{array}$ \\
\hline Data available for model validation & $\begin{array}{l}\text { Snow depth, snow }(0.1,0.2,0.3,0.4,0.5,0.6,0.7 \mathrm{~m}) \text { and ground temperature }(-0.1 \text {, } \\
-0.2,-0.3,-0.35 \mathrm{~m}) \text {, soil moisture }(-0.1,-0.2,-0.3 \mathrm{~m}) \text {, albedo, upward short- } \\
\text { and long-wave radiation }\end{array}$ \\
\hline Reference & Sato et al. (2001) \\
\hline \multicolumn{2}{|l|}{ (c) Tiksi, Sakha Republic, Russia } \\
\hline Location & $71^{\circ} 35^{\prime} 21^{\prime \prime} \mathrm{N}, 128^{\circ} 46^{\prime} 27^{\prime \prime} \mathrm{E}$ \\
\hline Altitude & $40 \mathrm{~m}$ \\
\hline Dominant vegetation type & Non-tussock sedge, dwarf shrubs, and moss tundra \\
\hline Soil & $\begin{array}{l}0-1 \mathrm{~cm} \text { : partially decomposed litter } \\
1-15 \mathrm{~cm} \text { : loam } \\
15-70 \mathrm{~cm} \text { : silt with gravel } \\
\text { Active layer thickness: } 70 \mathrm{~cm}\end{array}$ \\
\hline Climate & $\begin{array}{l}\text { Mean annual air temperature: }-13.5^{\circ} \mathrm{C} \\
\text { Annual precipitation: } 331 \mathrm{~mm}\end{array}$ \\
\hline fPAR and LAI* & $\begin{array}{l}\text { fPAR: } 0.00 \text { (Jan), } 0.00 \text { (Feb), } 0.00 \text { (Mar), } 0.00 \text { (Apr), } 0.03 \text { (May), } 0.29 \text { (Jun), } \\
0.45 \text { (Jul), } 0.47 \text { (Aug), } 0.28 \text { (Sep), } 0.04 \text { (Oct), } 0.00 \text { (Nov), } 0.00 \text { (Dec) } \\
\text { LAI: 0.00 (Jan), } 0.00 \text { (Feb), 0.00 (Mar), } 0.00 \text { (Apr), } 0.05 \text { (May), } 0.52 \text { (Jun), } \\
0.88 \text { (Jul), } 0.73 \text { (Aug), } 0.49 \text { (Sep), } 0.07 \text { (Oct), } 0.00 \text { (Nov), } 0.00 \text { (Dec) }\end{array}$ \\
\hline Data available for model validation & $\begin{array}{l}\text { Snow depth, ground temperature }(-0.1,-0.2,-0.3,-0.47,-1,-2,-3,-5,-10 \text {, } \\
-20,-30 \mathrm{~m}) \text {, soil moisture }(0,-0.05,-0.15,-0.3 \mathrm{~m}) \text {, albedo, upward short- and } \\
\text { long-wave radiation }\end{array}$ \\
\hline Reference & Kodama et al. (2007) and Watanabe et al. (2000) \\
\hline
\end{tabular}


Table 2. Continued.

(d) Yakutsk (Spasskaya Pad), Sakha Republic, Russia

$\begin{array}{ll}\text { Location } & 62^{\circ} 15^{\prime} 18^{\prime \prime} \mathrm{N}, 129^{\circ} 37^{\prime} 6^{\prime \prime} \mathrm{E} \\ \text { Altitude } & 220 \mathrm{~m} \\ \text { Dominant vegetation type } & \text { Larch forest } \\ \text { Soil } & 0-20 \mathrm{~cm} \text { : organic layer } \\ & \text { Upper mineral layer: sandy }\end{array}$

Upper mineral layer: sandy loam

Lower mineral layer: silty loam

(More than $80 \%$ of root: within a soil depth of $20 \mathrm{~cm}$ )

Active layer thickness: $1.2 \mathrm{~m}$

Climate

Mean annual air temperature: $-10.2^{\circ} \mathrm{C}$

Annual precipitation: $188 \mathrm{~mm}$

fPAR and $\mathrm{LAI}^{*}$

fPAR: 0.00 (Jan), 0.00 (Feb), 0.00 (Mar), 0.05 (Apr), 0.28 (May), 0.46 (Jun), 0.42 (Jul), 0.21 (Aug), 0.03 (Sep), 0.00 (Oct), 0.00 (Nov), 0.02 (Dec)

LAI: 0.00 (Jan), 0.00 (Feb), 0.00 (Mar), 0.00 (Apr), 0.07 (May), 0.58 (Jun), 1.05 (Jul), 0.81 (Aug), 0.28 (Sep), 0.04 (Oct), 0.00 (Nov), 0.00 (Dec)

Possible data for model validation Snow depth, ground temperature $(-0.1,-0.2,-0.4,-0.6,-0.8,-1.2 \mathrm{~m})$, soil moisture $(-0.1,-0.2,-0.4,-0.6,-0.8 \mathrm{~m})$, albedo, fPAR, upward short- and longwave radiation, energy and carbon fluxes

Reference Ohta et al. (2001, 2008, 2014), Kotani et al. (2013), and Lopez et al. (2007)

(e) Chokurdakh (Kodack/Krybaya), Sakha Republic, Russia

Location

Altitude

Dominant vegetation type

Soil

Climate

fPAR and LAI*

Data available for model validation

Reference $70^{\circ} 33^{\prime} 48^{\prime \prime} \mathrm{N}, 148^{\circ} 15^{\prime} 51^{\prime \prime} \mathrm{E}$

$9 \mathrm{~m}$

Tussock wetland/shrubs/sparse larch trees

Clay loam, silty clay loam

Active layer thickness: $0.4-0.7 \mathrm{~m}$

Mean annual air temperature: $-13.4^{\circ} \mathrm{C}$

Annual precipitation: $196 \mathrm{~mm}$

fPAR: 0.00 (Jan), 0.00 (Feb), 0.00 (Mar), 0.00 (Apr), 0.00 (May), 0.01 (Jun),

0.18 (Jul), 0.45 (Aug), 0.48 (Sep), 0.26 (Oct), 0.07 (Nov), 0.02 (Dec)

LAI: 0.00 (Jan), 0.00 (Feb), 0.00 (Mar), 0.00 (Apr), 0.02 (May), 0.32 (Jun),

0.91 (Jul), 0.79 (Aug), 0.41 (Sep), 0.15 (Oct), 0.00 (Nov), 0.00 (Dec)

Ground temperature $(-0.01,-0.05,-0.1,-0.2,-0.3,-0.4,-0.5,-0.75,-1.0$, $-1.5,-2.0,-2.5,-3.0,-4.0,-5.0,-5.5,-7.0,-10.0 \mathrm{~m})$, soil moisture $(-0.035$, $-0.145,-0.335,-0.535 \mathrm{~m})$, albedo, upward short- and long-wave radiation, energy and carbon fluxes

Iwahana et al. (2014)

\begin{tabular}{|c|c|}
\hline \multicolumn{2}{|l|}{ (f) Tura, Russia } \\
\hline Location & $64^{\circ} 12^{\prime} 32^{\prime \prime} \mathrm{N}, 100^{\circ} 27^{\prime} 49^{\prime \prime} \mathrm{E}$ \\
\hline Altitude & $250 \mathrm{~m}$ \\
\hline Dominant vegetation type & Larch forest (average age: 105 years in 2005) \\
\hline \multirow[t]{3}{*}{ Soil } & $10-20 \mathrm{~cm}$ organic layer \\
\hline & Cryosol \\
\hline & Active layer thickness: $1 \mathrm{~m}$ \\
\hline \multirow[t]{2}{*}{ Climate } & Mean annual air temperature: $-8.9^{\circ} \mathrm{C}$ \\
\hline & Annual precipitation: $360 \mathrm{~mm}$ \\
\hline fPAR and LAI average value extracted & fPAR: 0.00 (Jan), 0.00 (Feb), 0.00 (Mar), 0.01 (Apr), 0.20 (May), 0.48 (Jun), \\
\hline from $1 \mathrm{~km}$ grid MODIS satellite from & 0.52 (Jul), 0.49 (Aug), 0.29 (Sep), $0.10(\mathrm{Oct}), 0.00(\mathrm{Nov}), 0.00(\mathrm{Dec})$ \\
\hline 2001 to 2011 & LAI: 0.00 (Jan), 0.00 (Feb), 0.00 (Mar), 0.01 (Apr), 0.46 (May), 1.28 (Jun), \\
\hline (Sasai et al., 2011) & 1.43 (Jul), 1.17 (Aug), 0.48 (Sep), 0.17 (Oct), 0.00 (Nov), 0.00 (Dec) \\
\hline Data available for model validation & $\begin{array}{l}\text { Ground temperature }(-0.05,-0.1,-0.2,-0.4,-0.5 \mathrm{~m}) \text {, soil moisture }(-0.05 \text {, } \\
-0.1,-0.2,-0.4,-0.5 \mathrm{~m}) \text {, albedo, fPAR, upward short- and long-wave radiation, } \\
\text { energy and carbon fluxes }\end{array}$ \\
\hline Reference & Nakai et al. (2008) \\
\hline
\end{tabular}

* Average values extracted from $1 \mathrm{~km}$ grid MODIS satellite from 2001 to 2011 (Sasai et al., 2011). 
participants to use the parameters in the default settings for the provided boundary conditions, such as land cover type. In contrast, substage 1B allows tuning for the best reproduction of observations so that the parameter sensitivity among the sites can be evaluated. Process 1B is particularly important for the pan-Arctic region because many monitoring sites are located in temperate regions and models are generally validated against these environmental conditions.

We set the initial condition date to 1 September 1979, so that simulations started with a no-snow condition. The initial data for the model boundary conditions are available, as most stations can provide observation data for soil temperature and soil moisture profiles. However, each model could use its own method for initialization.

The spin-up process may also differ between models. However, we recommend continuing spin up until a steady state is achieved for the main variables (see Sect. 2.5). For example, Takata (2002) defined a threshold of a steady state in a slowly varying system as

$$
\frac{X_{n}-X_{n-1}}{X_{n}}<10^{-2}
$$

where $X$ is a physical variable (e.g. fluxes, ground temperature, soil moisture, or ice content). The subscript $n$ denotes the annual mean for the $n$th year.

For biogeochemical cycle models, in particular, we recommend maintaining spin up over at least 2000 years using the detrended meteorological driving data (also provided through ADS) because soil accumulation is quite slow owing to the low soil temperature and pre-industrial atmospheric $\mathrm{CO}_{2}$ concentrations (e.g. $280 \mathrm{ppmv}$ around the year 1750) until the soil carbon reaches equilibrium; the atmospheric $\mathrm{CO}_{2}$ concentration should then be increased to the current level (e.g. $340 \mathrm{ppmv}$ ) over 200 years or so (the period being dependent on the model). For the submission period (19792013), use of the historical atmospheric $\mathrm{CO}_{2}$ concentration is recommended for these models so that they are driven by time-variant $\mathrm{CO}_{2}$ concentrations.

\subsection{Model output variables}

We request participants to submit those variables listed in Table S1 (refer to the Supplement) in ASCII format with CSVtype files. The template file for output submission has been provided through ADS.

The variables for submission are categorized into six groups: (0) model driving, (1) energy and water budget, (2) snow dynamics, (3) vegetation, (4) subsurface hydrological and thermal states, and (5) carbon budget, in parallel to the analysis categories. Since the spectrum of the participating models is expected to be very large (ranging from physical to biogeochemical to ecosystem models; Fig. 4), we made an extensive list of output variables to cover the expected range. However, the actual output variables a model submits will be dependent on the model's specification. Con-

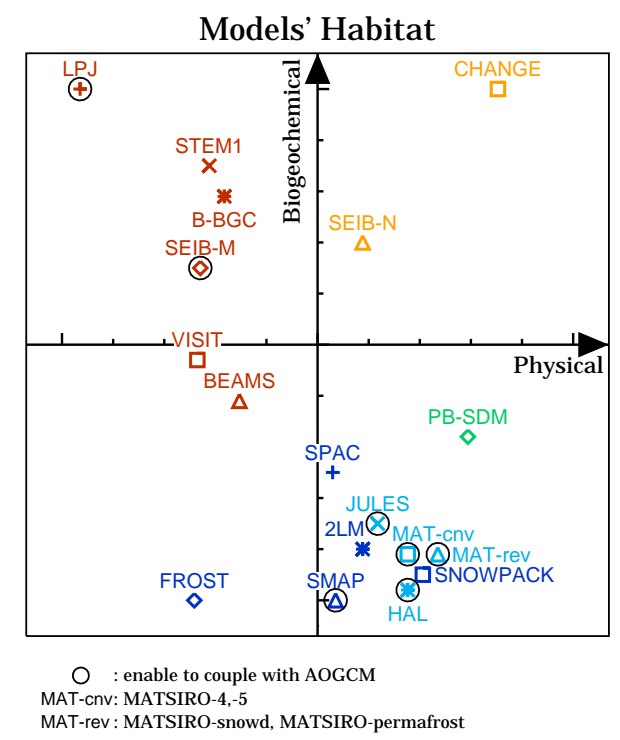

Figure 4. The habitat of models participating in the GTMIP. The vertical and horizontal axes show the ratio of the incorporation of biogeochemical processes and physical processes, respectively.

sidering this spread, the priority for each variable, classed at three levels, was set according to the necessity and availability for evaluation of the model performance. In addition, participants are requested to provide information on the status of the variables in their model (i.e. model driving, prescribed parameter, prognostic, diagnostic, or not applicable), through the provided questionnaire (Supplement, Table S3; provided through ADS), to identify the characteristics of the model.

Although the temporal resolution of a variable should depend on the model, we request submission of the variables with the minimum temporal resolution available for the model. For the models that provide daily outputs, the time for each day should be defined by the local time (FB: UTC -10 ; KV: UTC + 2; TK: UTC + 9; YK: UTC + 9; CH: UTC + 10; TR: UTC +7). Those models that use the no-leap calendar (365 days for all years) are requested to leave out 29 February. For those models with a 360-day calendar, data on days of year (DOYs) 90, 151, 212, 304, and 365 (corresponding to 31 March, 31 May, 31 July, 31 October, and 31 December in a no-leap year) should be omitted.

\subsection{Currently participating models}

Participation in GTMIP Stage 1 is voluntary and open to any interested modellers or institutions. A total of 16 TPMs have announced their participation in GTMIP Stage 1. These models are the permafrost model (FROST), physical snow models (SMAP and SNOWPACK), land surface models (2LM, HAL, JULES, several versions of MATSIRO, and SPAC-multilayer), a physical and biogeochemical soil dynamics model (PB-SDM), terrestrial biogeochemical models (BEAMS, Biome-BGC, STEM1, and VISIT), dynamic 
Table 3. The list of metrics for model performance evaluation for (a) energy and water budgets, (b) snowpack, (c) phenology, (d) subsurface hydrological and thermal states, and (e) the carbon budget.

\begin{tabular}{|c|c|c|c|c|}
\hline \multicolumn{5}{|c|}{ (a) Energy and water budget } \\
\hline Variable & Definition & Units & Direction $(+)$ & Time step \\
\hline $\begin{array}{l}\text { Rn_season, } \\
\text { Rn_annual }\end{array}$ & Seasonally and annually averaged net radiation & $\mathrm{W} \mathrm{m}^{-2}$ & downward & seasonal, annual \\
\hline $\begin{array}{l}\text { Qh_season, } \\
\text { Qh_annual }\end{array}$ & Seasonally and annually averaged sensible heat flux & $\mathrm{W} \mathrm{m}^{-2}$ & upward & seasonal, annual \\
\hline $\begin{array}{l}\text { Qle_season, } \\
\text { Qle_annual }\end{array}$ & Seasonally and annually averaged latent heat flux & $\mathrm{W} \mathrm{m}^{-2}$ & upward & seasonal, annual \\
\hline $\begin{array}{l}\text { ET_season, } \\
\text { ET_annual }\end{array}$ & $\begin{array}{l}\text { Seasonally and annually averaged total evapotran- } \\
\text { spiration }\end{array}$ & $\mathrm{mm}_{\text {day }}{ }^{-1}$ & upward & seasonal, annual \\
\hline $\begin{array}{l}\text { Qs_season, } \\
\text { Qs_annual }\end{array}$ & Seasonally and annually averaged surface runoff & $\mathrm{mm} \mathrm{day}^{-1}$ & out of soil column & seasonal, annual \\
\hline $\begin{array}{l}\text { Qsb_season, } \\
\text { Qsb_annual }\end{array}$ & Seasonally and annually averaged subsurface runoff & $\mathrm{mm}_{\text {day }}{ }^{-1}$ & out of soil column & seasonal, annual \\
\hline $\begin{array}{l}\text { Et_veg_season, } \\
\text { Et_veg_annual }\end{array}$ & $\begin{array}{l}\text { Seasonally and annually averaged transpiration of } \\
\text { vegetation }\end{array}$ & $\mathrm{mm}_{\text {day }}{ }^{-1}$ & upward & seasonal, annual \\
\hline $\begin{array}{l}\text { E_soil_season, } \\
\text { E_soil_annual }\end{array}$ & Seasonally and annually averaged soil evaporation & $\mathrm{mm}_{\text {day }}{ }^{-1}$ & upward & seasonal, annual \\
\hline $\begin{array}{l}\text { Wg_frac_season } \\
\text { Wg_frac_annual }\end{array}$ & $\begin{array}{l}\text { Seasonally and annually averaged fraction of sat- } \\
\text { uration of soil water content (wilting }=0 \text {, satura- } \\
\text { tion }=1 \text { ) }\end{array}$ & - & - & seasonal, annual \\
\hline $\begin{array}{l}\text { deltaWg_season, } \\
\text { deltaWg_annual }\end{array}$ & $\begin{array}{l}\text { Seasonally and annually averaged change of stored } \\
\text { soil moisture }\end{array}$ & $\mathrm{mm} \mathrm{day}^{-1}$ & - & seasonal, annual \\
\hline $\begin{array}{l}\text { alpha_season, } \\
\text { alpha_annual }\end{array}$ & $\begin{array}{l}\text { Seasonally and annually averaged short-wave } \\
\text { albedo }\end{array}$ & - & - & seasonal, annual \\
\hline $\begin{array}{l}\text { E_can_season, } \\
\text { E_can_annual }\end{array}$ & $\begin{array}{l}\text { Seasonally and annually averaged canopy intercep- } \\
\text { tion evaporation }\end{array}$ & $\mathrm{mm}_{\text {day }}{ }^{-1}$ & upward & seasonal, annual \\
\hline \multicolumn{5}{|l|}{ (b) Snowpack } \\
\hline Variable & Definition & Units & Direction $(+)$ & Time step \\
\hline $\begin{array}{l}\text { SWE_max } \\
\text { Date_SWE_max }\end{array}$ & $\begin{array}{l}\text { Annual maximum snow water equivalent and the } \\
\text { date reached }\end{array}$ & $\begin{array}{l}\mathrm{kg} \mathrm{m}^{-2} \\
\text { day }\end{array}$ & - & annual \\
\hline $\begin{array}{l}\text { SnD_max } \\
\text { Date_SnD_max }\end{array}$ & Annual maximum snow depth and the date reached & $\begin{array}{l}\mathrm{m} \\
\text { day }\end{array}$ & - & annual \\
\hline $\begin{array}{l}\text { SnowDuration } \\
\text { Date_start_snow_cover }\end{array}$ & $\begin{array}{l}\text { Annual duration of snow cover and the date of snow } \\
\text { cover start/end }\end{array}$ & day & - & annual \\
\hline $\begin{array}{l}\text { Sub_snow_season, } \\
\text { Sub_snow_annual }\end{array}$ & $\begin{array}{l}\text { Seasonally and annually averaged total sublimation } \\
\text { from the ground snowpack }\end{array}$ & $\mathrm{mm} \mathrm{day}^{-1}$ & upward & annual \\
\hline \multicolumn{5}{|l|}{ (c) Phenology } \\
\hline Variable & Definition & Units & Direction $(+)$ & Time step \\
\hline LAI_max & Annual maximum leaf area index & $\mathrm{m}^{2} \mathrm{~m}^{-2}$ & - & annual \\
\hline GrowSeasonLentgh & $\begin{array}{l}\text { Growing season length and the date of start/end of } \\
\text { growing season }\end{array}$ & day & - & annual \\
\hline
\end{tabular}

global vegetation models (LPJ and SEIB-DGVM, coupled with a land surface model (Noah-LSM) or stand-alone), and a coupled hydrological and biogeochemical model (CHANGE). The models with higher degrees of complexity in their treatment of physical processes are 2LM, CHANGE, FROST, HAL, JULES, MATSIRO, PB-SDM, SNOWPACK, SMAP, and SPAC-multilayer. The models with higher degrees of complexity in their treatment of biogeochemical processes are BEAMS, Biome-BGC, CHANGE, LPJ, SEIBDGVM, STEM1, and VISIT. The models enabled to couple with AOGCMs (currently, JULES, HAL, LPJ, MATSIRO, and SMAP) make up about $30 \%$ of the participating models.

To illustrate the variability of the participating models with respect to the implemented physical and biogeochemical processes, we created a diagram showing the habitat of the currently participating models (Fig. 4) by incorporating the model survey results referred to in the previous section. The spread of the models is large for both physical and biogeochemical process dimensions, which will benefit the evalua- 
Table 3. Continued.

(d) Subsurface hydrological and thermal states

\begin{tabular}{|c|c|c|c|c|}
\hline Variable & Definition & Units & Direction $(+)$ & Time step \\
\hline $\begin{array}{ll}\text { ALT } & \text { or } \\
\text { ThawDepth_max } & \end{array}$ & $\begin{array}{l}\text { Active layer thickness (permafrost region) or annual } \\
\text { maximum thawing depth (seasonal frozen ground) } \\
\text { and the date reached }\end{array}$ & $\mathrm{m}$ & - & annual \\
\hline FrozenDepth_max & Annual maximum frozen depth and the date reached & $\mathrm{m}$ & - & annual \\
\hline Tg_range_depth & $\begin{array}{l}\text { Annual range of soil temperature in pre-defined soil } \\
\text { layer }\end{array}$ & $\mathrm{K}$ & - & annual \\
\hline Wg_frozfrac_max_depth & $\begin{array}{l}\text { Annual maximum fraction of soil moisture mass in } \\
\text { the solid phase in pre-defined soil layer }\end{array}$ & - & - & annual \\
\hline \multicolumn{5}{|l|}{ (e) Carbon budget } \\
\hline Variable & Definition & Units & Direction $(+)$ & Time step \\
\hline $\begin{array}{l}\text { NPP_annual } \\
\text { NPP_growing }\end{array}$ & $\begin{array}{l}\text { Annual and growing season net primary production } \\
\text { on land }\end{array}$ & $\begin{array}{l}\mathrm{kgC} \mathrm{m}^{-2} \text { year }^{-1} \\
\mathrm{kgC} \mathrm{m}^{-2} \text { duration }^{-1}\end{array}$ & downward & annual, growing season \\
\hline $\begin{array}{l}\text { GPP_annual } \\
\text { GPP_growing }\end{array}$ & Annual gross primary production & $\begin{array}{l}\mathrm{kgC} \mathrm{m}^{-2} \text { year }^{-1} \\
\mathrm{kgC} \mathrm{m}^{-2} \text { duration }^{-1}\end{array}$ & downward & annual, growing season \\
\hline $\begin{array}{l}\mathrm{Rh} \_ \text {annual } \\
\mathrm{Rh} \text { growing }\end{array}$ & Annual heterotrophic respiration on land & $\begin{array}{l}\mathrm{kgC} \mathrm{m}^{-2} \text { year }^{-1} \\
\mathrm{kgC} \mathrm{m}^{-2} \text { duration }^{-1}\end{array}$ & upward & annual, growing season \\
\hline $\begin{array}{l}\text { Ra_annual } \\
\text { Ra_growing }\end{array}$ & Annual autotrophic (plant) respiration on land & $\begin{array}{l}\mathrm{kgC} \mathrm{m}^{-2} \text { year }^{-1} \\
\mathrm{kgC} \mathrm{m}^{-2} \text { duration }^{-1}\end{array}$ & upward & annual, growing season \\
\hline $\begin{array}{l}\text { NEP_annual } \\
\text { NEP_growing }\end{array}$ & $\begin{array}{l}\text { Annual net ecosystem productivity (i.e. NPP }-\mathrm{Rh} \text { ) } \\
\text { on land }\end{array}$ & $\begin{array}{l}\mathrm{kgC} \mathrm{m}^{-2} \text { year }^{-1} \\
\mathrm{kgC} \mathrm{m}^{-2} \text { duration }^{-1}\end{array}$ & downward & annual, growing season \\
\hline $\begin{array}{l}\mathrm{Re} \text { _annual } \\
\mathrm{Re} \text { _growing }\end{array}$ & $\begin{array}{l}\text { Annual and growing season ecosystem respiration } \\
\text { (i.e. } \mathrm{Ra}+\mathrm{Rh} \text { ) on land }\end{array}$ & $\begin{array}{l}\mathrm{kgC} \mathrm{m}^{-2} \text { year }^{-1} \\
\mathrm{kgC} \mathrm{m}^{-2} \text { duration }^{-1}\end{array}$ & downward & annual, growing season \\
\hline cBiomass_annual & Stored carbon mass in biomass pool & $\mathrm{kgC} \mathrm{m}^{-2}$ & - & annual \\
\hline TotCarLitSoil & Stored carbon mass in litter pool and soil & $\mathrm{kgC} \mathrm{m}^{-2}$ & - & annual \\
\hline cTurnoverRate_biomass & Turnover rate of carbon in biomass pool & 1 year $^{-1}$ & - & - \\
\hline cTurnoverRate_soil & Turnover rate of carbon litter pool and soil & 1 year $^{-1}$ & - & - \\
\hline
\end{tabular}

tion and attribute examinations of the models regarding their ability to reproduce observations.

\section{Analysis plan and exemplary results}

This section presents the analysis plan for GTMIP Stage 1 and sample outputs based on already submitted materials. To answer the key questions for the target processes proposed in Sect. 2.1, we plan to analyse the model output by describing the model-model and model-observation differences, discerning the cause of these differences, and investigating parameter sensitivity. The outputs of multiple models will be compared in terms of the metrics shown in Table 3. These metrics are divided into five categories (i.e. energy and water budget, snowpack, phenology, subsurface hydrological and thermal states, and carbon budget). For terrestrial climate simulations on the decadal scale, the most important outputs are the latent heat flux (energy and water budget) and the net ecosystem exchange (carbon budget). The latent heat flux (evapotranspiration) is the essential driver of precipitation inland at high latitudes owing to high rates of recycling (e.g. Dirmeyer et al., 2009; Saito et al., 2006). Net ecosystem exchange (NEE) plays a fundamental role in determining global $\mathrm{CO}_{2}$ concentrations by determining whether a site forms a carbon source or sink (e.g. Abramowitz et al., 2008; McGuire et al., 2012). NEE represents the net land-atmosphere $\mathrm{CO}_{2}$ flux, and a positive NEE represents net loss of $\mathrm{CO}_{2}$ from the land to the atmosphere (i.e. carbon source; McGuire et al., 2012). Although NEE is commonly used for tower flux observations and some TPMs, the net ecosystem production (NEP) is used in GTMIP for both the observed and simulated values because it is more widely used in non-biogeochemical communities. A positive (negative) value of NEP represents a carbon sink (source).

Analyses will be organized and conducted in the following manner. Topical analyses, constituting major subsets of the project outcomes, will evaluate characteristics of model performances and their inter-site variations within each of the above five categories, while cross-sectional analyses between categories will explore the functionality and strength of interactions between processes. These analyses will be utilized for mining crucial processes to improve the site-level TPMs as well as large-scale GCM/ESM components.

First, the focus will be on model output variability for both the inter-annual and the inter-decadal timescales, based on the output time series over more than 30 years. Inter-site differences will also be evaluated for the four GRENE-TEA sites in the Arctic region, each of which has distinct characteristics. The vegetation type for three of the four sites is 


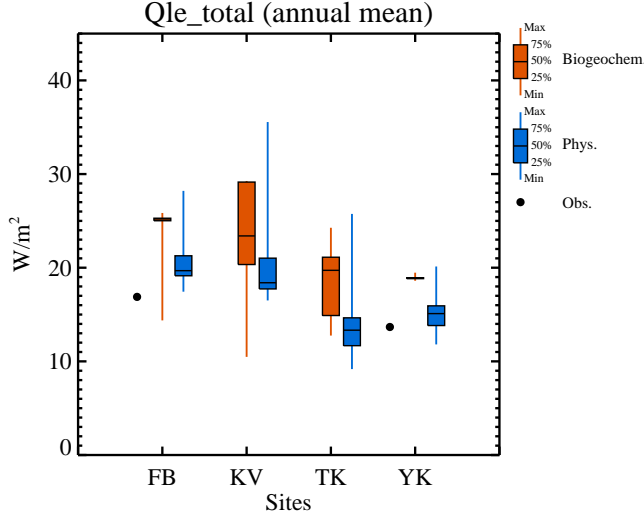

Figure 5. Example comparison of model outputs with observations, and the inter-model range for the annual mean latent heat flux for averages from 1980 to 2013. The results of biogeochemical and physical models are shown by boxes and lines in orange and blue, respectively. The biogeochemical models included are BEAMS, Biome-BGC, CHANGE, SEIB-DGVM, and VISIT, while the physical models are 2LM, JULES, MATSIRO, and PB-SDM. The orange and blue horizontal lines indicate medians. The bottom and top of the boxes correspond to the 25th and 75th percentiles of the average values, for 1980-2013 (except BEMAS, which is for 2001-2011), of model outputs. The bottom and top of the lines show the minimum and maximum outputs from the participating models, respectively. The dots show the observed average values for 2011, 2012, and 2013 at FB and for 1998, 2001, 2003, 2004, 2007, and 2008 at YK.

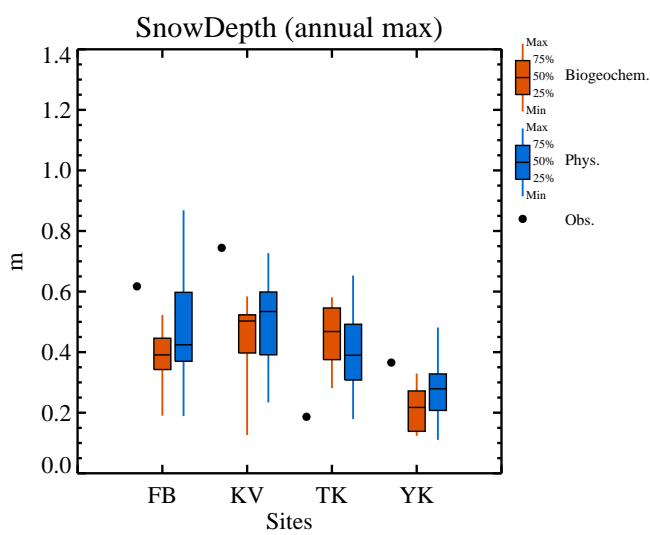

Figure 6. As for Fig. 3, except the plot displays annual maximum snow depth. The physical models include 2LM, JULES, MATSIRO, PB-SDM, SMAP, and SNOWPACK (for FB and KVTK only). The observation shows the average values for 1980-2012, 1996-2013, 1980-2008, and 1980-2008 at FB, KV, TK, and YK, respectively.

forest (two evergreen conifer: $\mathrm{FB}$ and $\mathrm{KV}$; one deciduous conifer: YK) and the remaining site is tundra (TK). Three sites $(\mathrm{FB}, \mathrm{TK}$, and $\mathrm{YK}$ ) are in the permafrost region, while $\mathrm{KV}$ is underlain by seasonally frozen ground. Figures $5-8$ show statistical summary comparisons of the model outputs by site (the land cover and soil type parameters used for the

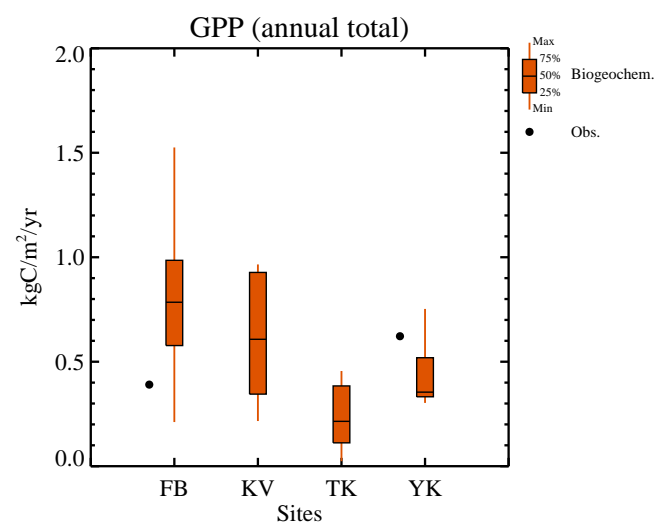

Figure 7. As for Fig. 3, except the plot displays annual gross primary production. The relevant biogeochemical models include BEAMS, Biome-BGC, CHANGE, LPJ, SEIB-DGVM, STEM1, and VISIT. The observation shows the average values for 20112013 and 2004-2012 at FB and YK, respectively.

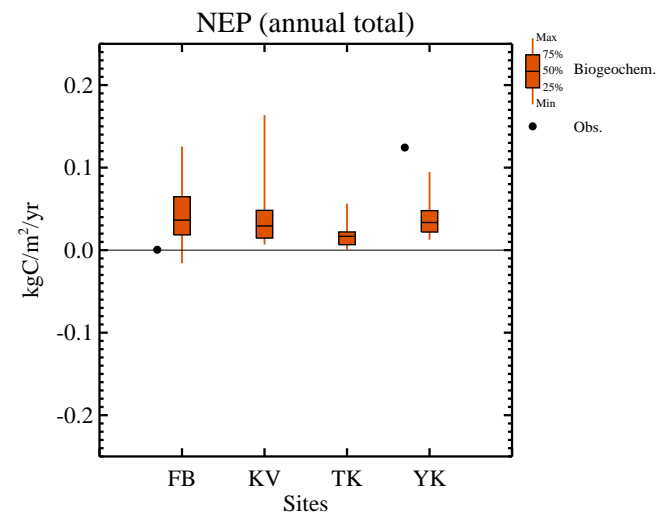

Figure 8. As for Fig. 5, except the plot displays annual net primary production.

simulations are shown in Table 2), expressing inter-model variations for physical and biogeochemical models using box plots for four variables of the metrics mentioned above: the annual mean latent heat flux (Qle_total_an), the annual maximum snow depth (SnowDepth_max), the annual gross primary production (GPP_an), and the annual net ecosystem production (NEP_an), respectively. When observed values were available (i.e. latent heat flux for FB for 2011-2013 and YK for 1998, 2001, 2003, 2004, 2007, and 2008), they are shown by black dots.

Second, the cause or attributes of the differences among models, or between models and observations, will be explored by employing statistical evaluations such as multivariate analyses and time series analyses on the metrics and individual eco-climate variables. This will improve understanding of the interrelation between the incorporated processes in each model. Figure 9 shows an exemplary comparison of a seasonal transition in the snow-permafrost-vegetation subsystem, expressed similarly by box plots. The figure summa- 

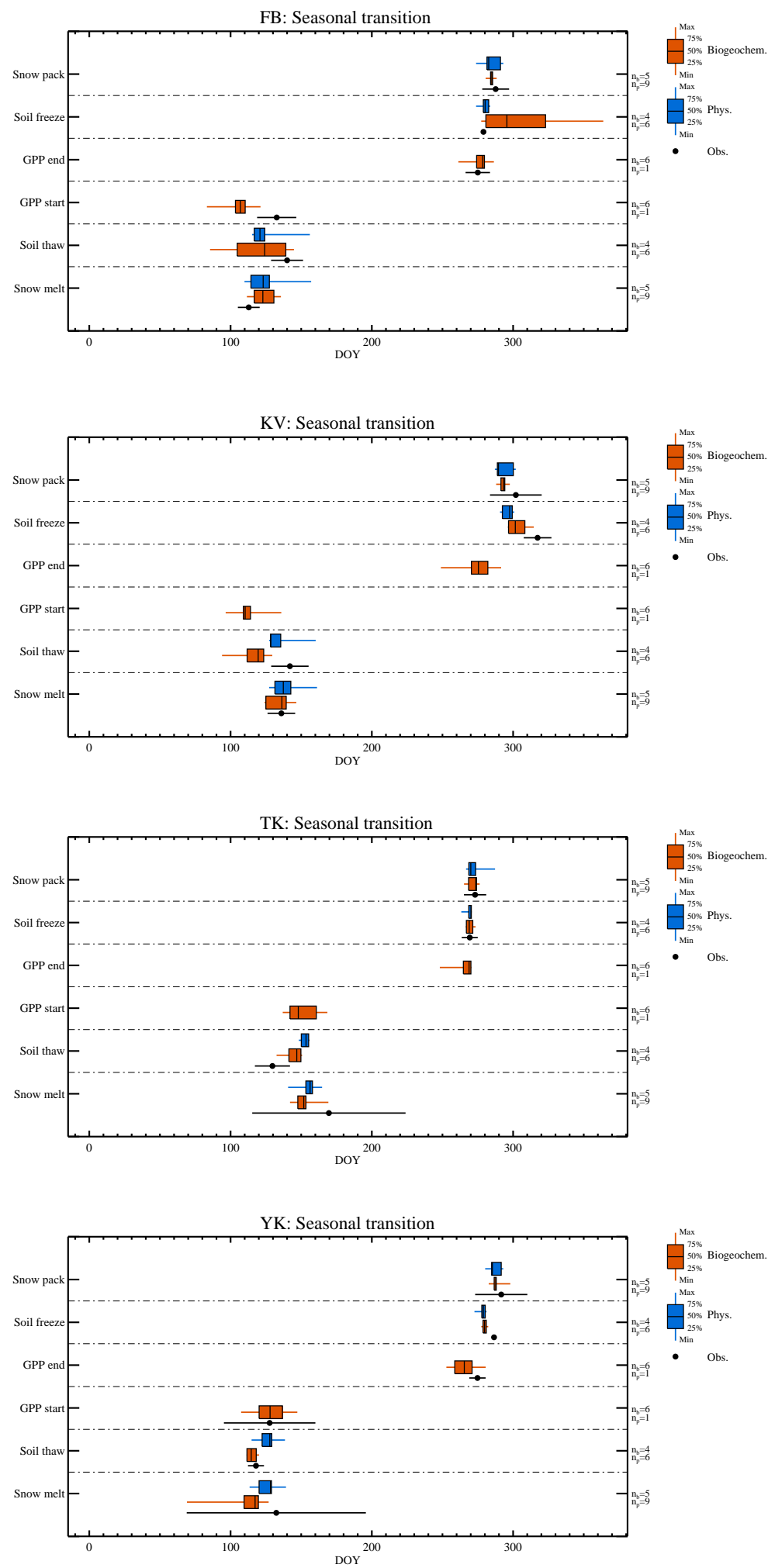

Figure 9. Example of seasonal transitions in ground temperature, snow, and vegetation among models. 
rizes the average dates for (from bottom to top) the completion of snowmelt, the thawing of the top soil layer, the start and end of greening, the freezing of the top soil layer, and the start of seasonal snow accumulation. A comparison of the timings of these events over years and sites will illustrate the individual model's characteristic behaviour in seasonal transitions, and their strength regarding process interactions, in combination with ordinary multivariate analysis techniques.

Finally, sensitivity tests for the model parameters are planned to quantify the effect of parameter sensitivity on the model's reproducibility.

\section{Summary}

This paper presented an overview of the GTMIP activity and the experiment protocol for the Stage 1 intercomparison, with site simulations using the GRENE-TEA site observation data in the pan-Arctic region for the previous 3 decades. We described the framework of our project including targets, and provided data sets, conditions on model integration, lists of model output variables, and the habitat of currently participating models. We also included analysis plans and exemplary results to give an outlook of the modelmodel and model-observation comparisons with respect to the major metrics defined for the energy budget, snowpack dynamics, and the carbon budget. This model intercomparison project was realized through a tight collaboration between the GRENE-TEA-participating modelling and field scientists. Additionally, we expect to offer insightful demonstrations of various cold-region terrestrial physical and biogeochemical TPMs and valuable information for future improvements of the relevant models. All meteorological driving data for this project have already been made publicly available through ADS. The model outputs and comprehensive results from the GTMIP, which we hope will provide a useful benchmark data set for the community, will also be available to the public at the end of the project.

\section{The Supplement related to this article is available online at doi:10.5194/gmd-8-2841-2015-supplement.}

Acknowledgements. This study is supported by the GRENE Arctic Climate Change Research Project, Ministry of Education, Culture, Sports, Science and Technology, Japan.

Edited by: D. Roche

\section{References}

Abramowitz, G., Leuning, R., Clark, M., and Pitman, A.: Evaluating the performance of land surface models, J. Climate, 21, 54685481, 2008.

Adler, R. F., Huffman, G. J., Chang, A., Ferraro, R., Chang, A., Ferraro, R., Xie, P. P., Janowiak, J., Rudolf, B., Scheneider, U., Curtis, S., Bolvin, D., Gruber, A., Susskind, J., Arkin, P., and Nelkin, E.: The Version-2 Global Precipitation Climatology Project (GPCP) Monthly Precipitation Analysis (1979-Present), J. Hydrometeorol., 4, 1147-1167, 2003.

Ahlstrom, A., Schurgers, G., Arneth, A., and Smith, B.: Robustness and uncertainty in terrestrial ecosystem carbon response to CMIP5 climate change projections, Environ. Res. Lett., 7, 044008, doi:10.1088/1748-9326/7/4/044008, 2012.

Anav, A., Friedlingstein, P., Kidston, M., Bopp, L., Ciais, P., Cox, P., Jones, C., Jung, M., Myneni, R., and Zhu, Z.: Evaluating the land and ocean components of the global carbon cycle in the CMIP5 Earth system models, J. Climate, 26, 6801-6843, 2013.

Arora, V. K., Boer, G. J., Friedlingstein, P., Eby, M., Jones, C. D., Christian, J. R., Bonan, G., Bopp, L., Brovkin, V., Cadule, P., Hajima, T., Ilyina, T., Lindsay, K., Tjiputra, J. F., and Wu, T.: Carbon-concentration and carbon-climate feedbacks in CMIP5 Earth system models, J. Climate, 26, 5289-5314, 2013.

Brown, R. D. and Robinson, D. A.: Northern Hemisphere spring snow cover variability and change over 1922-2010 including an assessment of uncertainty, The Cryosphere, 5, 219-229, doi:10.5194/tc-5-219-2011, 2011.

Brutel-Vuilmet, C., Ménégoz, M., and Krinner, G.: An analysis of present and future seasonal Northern Hemisphere land snow cover simulated by CMIP5 coupled climate models, The Cryosphere, 7, 67-80, doi:10.5194/tc-7-67-2013, 2013.

Cramer, W., Kicklighter, D. W., Bondeau, A., Moore, B., Churkina, G., Nemry, B., Ruimy, A., Schloss, A. L., and the participants of the Potsdam NPP model intercomparison.: Comparing global models of terrestrial net primary productivity (NPP): overview and key results, Glob. Change Biol., 5, 1-15, 1999.

Dee, D. P., Uppalaa, S. M., Simmonsa, A. J. Berrisford, P., Poli, P., Kobayashi, S., Andrae, U., Balmaseda, M. A., Balsamo, G., Bauer, P., Bechtold, P., Beljaars, A. C. M., van de Berg, L., Bidlot, J., Bormann, N., Delsol, C., Dragani, R., Fuentes, M., Geer, A. J., Haimberger, L., Healy, S. B., Hersbach, H., Hólm, E. V., Isaksen, L., Kallberg, P., Kohler, M., Matricardi, M., McNally, A. P., Monge-Sanz, B. M., Morcrette, J.-J., Park, B.-K., Peubey, C., de Rosnay, P., Tavolato, C., Thepaut, J.-N., and Vitart, F.: The ERA-Interim reanalysis: configuration and performance of the data assimilation system, Q. J. Roy. Meteor. Soc., 137, 553-597, 2011.

de Gonçalves, L. G. G., Borak, J. S., Costa, M. H., Saleska, S. R., Baker, I., Restrepo-Coupe, N., Muza, M. N., Poulter, B., Verbeeck, H., Fisher, J. B., Arain, M. A., Arkin, P., Cestaro, B. P., Christoffersen, B., Galbraith, D., Guan, X., van den Hurk, B. J. J. M., Ichii, K., Imbuzeiro, H. M. A., Jain, A. K., Levine, N., Lu, C., Miguez-Macho, G., Roberti, D. R., Sahoo, A., Sakaguchi, K., Schaefer, K., Shi, M., Shuttleworth, W. J., Tian, H., Yang, Z.-L., and Zeng, X.: Overview of the large-scale biosphere-atmosphere experiment in Amazonia Data Model Intercomparison Project (LBA-DMIP), Agr. Forest Meteorol., 182-183, 111-127, 2013. 
Dirmeyer, P. A., Schlosser, C. A., and Brubaker, K. L.: Precipitation, recycling, and land memory: An integrated analysis, J. Hydrometeorol., 10, 278-288, 2009.

Ekici, A., Chadburn, S., Chaudhary, N., Hajdu, L. H., Marmy, A., Peng, S., Boike, J., Burke, E., Friend, A. D., Hauck, C., Krinner, G., Langer, M., Miller, P. A., and Beer, C.: Site-level model intercomparison of high latitude and high altitude soil thermal dynamics in tundra and barren landscapes, The Cryosphere, 9, 1343-1361, doi:10.5194/tc-9-1343-2015, 2015.

Etchevers, P., Martin, E., Brown, R., Fierz, C., Lejeune, Y., Bazile, E., Boone, A., Dai, Y. J., Essery, R., Fernandez, A., Gusev, Y., Jordan, R., Koren, V., Kowalczyk, E., Nasonova, N. O., Pyles, R. D., Schlosser, A., Shmakin, A. B., Smirnova, T. G., Strasser, U., Verseghy, D., Yamazaki, T., Yang, Z. L.: Validation of the surface energy budget simulated by several snow models, Ann. Glaciol., 38, 150-158, 2004.

Essery, R., Rutter, N., Pomeroy, J., Baxter R., Stahli, M., Gustafsson, D., Barr, A., Bartlett, P., and Elder, K.: SnowMIP2: An evaluation of forest snow process simulations, B. Am. Meteorol. Soc., 90, 1120-1135, doi:10.1175/2009BAMS2629.1, 2009.

Friedlingstein, P., Cox, P., Betts, R., Bopp, L., Bloh, W. V., Brovkin, V., Cadule, P., Doney, S., Eby, M., Fung, I., Bala, G., John, J., Jones, C., Joos, F., Kato, T., Kawamiya, M., Knorr, W., Lindsay, K., Matthews, H. D., Raddatz, T., Rayner, P., Reick, C., Roeckner, E., Schnitzler, K. G., Schnur, R., Strassmann, K., Weaver, J., Yoshikawa, C., and Zeng, N.: Climate-carbon cycle feedback analysis: Results from the C 4 MIP model intercomparison, J. Climate, 19, 3337-3353, 2006.

Hajima, T., Tachiiri, K., Ito, A., and Kawamiya, M.: Uncertainty of concentration-terrestrial carbon feedback in Earth System Models, J. Climate, 27, 3425-3445, 2014.

Harris, I., Jones, P. D., Osborn, T. J., and Listera, D. H.: Updated high-resolution grids of monthly climatic observations the CRU TS3.10 Dataset, Int. J. Climatol., 34, 623-642, 2014.

Henderson-Sellers, A., Yang, Z. L., and Dickinson, R. E.: The Project for intercomparison of land surface schemes (PILPS), B. Am. Meteorol. Soc., 74, 1335-1349, 1993.

Huntzinger, D. N., Schwalm, C., Michalak, A. M., Schaefer, K., King, A. W., Wei, Y., Jacobson, A., Liu, S., Cook, R. B., Post, W. M., Berthier, G., Hayes, D., Huang, M., Ito, A., Lei, H., Lu, C., Mao, J., Peng, C. H., Peng, S., Poulter, B., Riccuito, D., Shi, X., Tian, H., Wang, W., Zeng, N., Zhao, F., and Zhu, Q.: The North American Carbon Program Multi-Scale Synthesis and Terrestrial Model Intercomparison Project - Part 1: Overview and experimental design, Geosci. Model Dev., 6, 2121-2133, doi:10.5194/gmd-6-2121-2013, 2013.

Ichii, K., Suzuki, T., Kato, T., Ito, A., Hajima, T., Ueyama, M., Sasai, T., Hirata, R., Saigusa, N., Ohtani, Y., and Takagi, K.: Multi-model analysis of terrestrial carbon cycles in Japan: limitations and implications of model calibration using eddy flux observations, Biogeosciences, 7, 2061-2080, doi:10.5194/bg-72061-2010, 2010.

Ichii, K., Kondo, M., Lee, Y.-H., Wang, S.-Q., Kim, J., Ueyama, M., Lim, H.-J., Shi, H., Suzuki, T., Ito, A., Kwon, H., Ju, W., Huang, M., Sasai, T., Asanuma, J., Han, S., Hirano, T., Hirata, R., Kato, T., Li, S.-G., Li, Y.-N., Maeda, T., Miyata, A., Matsuura, Y., Murayama, S., Nakai, Y., Ohta, T., Saitoh, T., Saigusa, N., Takagi, K., Tang, Y.-H., Wang, H.-M., Yu, G.-R., Zhang, Y.-P., and Zhao, F.-H.: Site-level model-data synthesis of terrestrial carbon fluxes in the CarboEastAsia eddy-covariance observation network: toward future modeling efforts, J. Forest Res., 18, 13-20, 2013.

IPCC: Climate Change 2013: The Physical Science Basis, Contribution of Working Group I to the Fifth Assessment Report of the Intergovernmental Panel on Climate Change edited by: Stocker, T. F., Qin, D., Plattner, G.-K., Tignor, M., Allen, S. K., Boschung, J., Nauels, A., Xia, Y., Bex, V., and Midgley, P. M., Cambridge University Press, Cambridge, UK and New York, NY, USA, 1535 pp., 2013.

Iwahana, G., Takano, S., Petrov, R. E., Tei, S., Shingubara, R., Maximov, T. C., Fedrov, A. N., Desyatkin, A. R., Nikolaev, A. N., Desyatkin, R. V., Sugimoto, A.: Geocryological characteristics of the upper permafrost in a tundraforest transition of the Indigirka River Valley, Russia, Polar Sci., 8, 96-113, doi:10.1016/j.polar.2014.01.005, 2014.

Jung, M., Le Maire, G., Zaehle, S., Luyssaert, S., Vetter, M., Churkina, G., Ciais, P., Viovy, N., and Reichstein, M.: Assessing the ability of three land ecosystem models to simulate gross carbon uptake of forests from boreal to Mediterranean climate in Europe, Biogeosciences, 4, 647-656, doi:10.5194/bg-4-647-2007, 2007.

Kodama, Y., Sato, N., Yabuki, H., Ishii, Y., Nomura, M., and Ohata, T.: Wind direction dependency of water and energy fluxes and synoptic conditions over a tundra near Tiksi, Siberia, Hydrol. Process., 21, 2028-2037, 2007.

Kotani, A., Kononov, A. V., Ohta, T., and Maximov, T. C.: Temporal variations in the linkage between the net ecosystem exchange of water vapour and $\mathrm{CO}_{2}$ over boreal forests in eastern Siberia, Ecohydrology, 7, 209-225, doi:10.1002/eco.1449, 2013.

Koven, C. D., Ringeval, B., Friedlingstein, P., Ciais, P., Cadule, P., Khvorostyanov, D., Krinner, G., and Tarnocai, C.: Permafrost carbon-climate feedbacks accelerate global warming, P. Natl. Acad. Sci. USA, 108, 14769-14774, doi:10.1073/pnas.1103910108, 2011.

Koven, C. D., Riley, W. J., and Stern, A.: Analysis of permafrost thermal dynamics and response to climate change in the CMIP5 Earth System Models, J. Climate, 26, 1877-1900, 2013.

Lopez, M. L., Saito, H., Kobayashi, K., Shirota, T., Iwahana, G., Maximov, T. C., and Fukuda, M.: Interannual environmental-soil thawing rate variation and its control on transpiration from Larix cajanderi, Central Yakutia, Eastern Siberia, J. Hydrol., 338, 251260, doi:10.1016/j.jhydrol.2007.02.039, 2007.

McGuire, A. D., Christensen, T. R., Hayes, D., Heroult, A., Euskirchen, E., Kimball, J. S., Koven, C., Lafleur, P., Miller, P. A., Oechel, W., Peylin, P., Williams, M., and Yi, Y.: An assessment of the carbon balance of Arctic tundra: comparisons among observations, process models, and atmospheric inversions, Biogeosciences, 9, 3185-3204, doi:10.5194/bg-9-3185-2012, 2012.

Morales, P., Sykes, M. T., Prentice, I. C., Smith, P., Smith, B., Bugmann, H., Zierl, B., Friedlingstein, P., Viovy, N., Sabate, S., Sanchez, A., Pla, E., Gracia, C. A., Sitch, S., Arneth, A., and Ogee, J.: Comparing and evaluating process-based ecosystem model predictions of carbon and water fluxes in major European forest biomes, Glob. Change Biol., 11, 2211-2233, 2005.

Nakai, T., Kim, Y., Busey, R. C., Suzuki, R., Nagai, S., Kobayashi, H., Park, H., Sugiura, K., and Ito, A.: Characteristics of evapotranspiration from a permafrost black spruce forest in interior Alaska, Polar Sci., 7, 136-148, 2013. 
Nakai, Y., Matsuura, Y., Kajimoto, T., Abaimov, A. P., Yamamoto, S., and Zyryanova, O. A.: Eddy covariance $\mathrm{CO}_{2}$ flux above a Gmelin larch forest in continuous permafrost of central Siberia during a growing season, Theor. Appl. Climatol., 93, 133-147, doi:10.1007/s00704-007-0337-x, 2008.

Ohta, T., Hiyama, T., Tanaka, H., Kuwada, T., Maximov, T. C., Ohata, T., and Fukushima, Y.: Seasonal variation in the energy and water exchanges above and below a larch forest in Eastern Siberia, Hydrol. Process., 15, 1459-1476, 2001.

Ohta, T., Maximov, T. C., Dolman, A. J., Nakai, T., van der Molen, M. K., Kononov, A. V., Maximov, A. P., Hiyama, T., Iijima, Y., Moors, E. J., Tanaka, H., Toba, T., Yabuki, H.: Interannual variation of water balance and summer evapotranspiration in an Eastern Siberian larch forest over a 7-year period (1998-2006), Agr. Forest Meteorol., 148, 1941-1953, 2008.

Ohta, T., Kotani, A., Iijima, Y., Maximov, T. C., Ito, S., Hanamuraa, M., Kononov, A. V., and Maximov, A. P.: Effects of waterlogging on water and carbon dioxide fluxes and environmental variables in a Siberian larch forest, 1998-2011, Agr. Forest Meteorol., 188, 64-75, 2014.

Piao, S., Stich, S., Ciais, P., Friedlingstein, P., Peylin, P., Wang, X., Ahstrom, A., Anav, A., Candell, J. G., Cong, N., Huntingford, C., Jung, M., Levis, S., Levy, P. E., Li, J., Lin, X., Lomas, M. R., Lu, M., Luo, Y., Ma, Y., Myneni, R. B., Poulter, B., Sun, Z., Wang, T., Viovy, N., Zaehle, S., and Zeng, N.: Evaluation of terrestrial carbon cycle models for their response to climate variability and $\mathrm{CO}_{2}$ trends, Glob. Change Biol., 19, 2117-2132, 2013.

Qian, H., Joseph, R., and Zeng, N.: Enhanced terrestrial carbon uptake in the Northern High Latitudes in the 21st century from the coupled carbon cycle climate model intercomparison project model projections, Glob. Change Biol., 16, 641-656, 2010.

Rawlins, M. A., McGuire, A. D., Kimball, J. S., Dass, P., Lawrence, D., Burke, E., Chen, X., Delire, C., Koven, C., MacDougall, A., Peng, S., Rinke, A., Saito, K., Zhang, W., Alkama, R., Bohn, T. J., Ciais, P., Decharme, B., Gouttevin, I., Hajima, T., Ji, D., Krinner, G., Lettenmaier, D. P., Miller, P., Moore, J. C., Smith, B., and Sueyoshi, T.: Assessment of model estimates of landatmosphere $\mathrm{CO}_{2}$ exchange across Northern Eurasia, Biogeosciences, 12, 4385-4405, doi:10.5194/bg-12-4385-2015, 2015.

Saito, K., Yasunari, T., and Takata, K.: Relative roles of large-scale orography and land surface processes in the global hydroclimate. Part II: Impacts on hydroclimate over Eurasia, J. Hydrometeorol., 7, 642-659, 2006.

Saito, K., Miyazaki, S., Mori, J., Ise, T., Arakida, H., Sueyoshi, T., Hajima, T., Iijima, Y., Yamazaki, T., and Sugimoto, A.: GTMIP meteorological driving dataset for the GRENE-TEA observation sites (level 0.2), 0.20, Arctic Data archive System (ADS), Japan, https://ads.nipr.ac.jp/dataset/A20141009-005 (last access: 2 September 2015), 2014a.

Saito, K., Miyazaki, S., Mori, J., Ise, T., Arakida, H., Suzuki, R., Sato, A., Iijima, Y., Yabuki, H., Iijima, Y., Sueyoshi, T., Hajima, T., Sato, H., Yamazaki, T., and Sugimoto, A.: GTMIP meteorological driving dataset for the GRENE-TEA observation sites (level 1.0), 1.00, Arctic Data archive System (ADS), Japan, available at: https://ads.nipr.ac.jp/dataset/A20141009-006 (last access: 2 September 2015), 2014b.

Saito, K., Sasai, T., Miyazaki, S., Mori, J., Ise, T., Arakida, H., Sueyoshi, T., Hajima, T., Iijima, Y., Yamazaki, T., and Sugimoto, A.: GTMIP fraction of photosynthetically active radiation
(fPAR) and leaf area index (LAI) for the GRENE-TEA observation sites (level 1.0), 1.00, Arctic Data archive System (ADS), Japan, available at: https://ads.nipr.ac.jp/dataset/A20141009-007 (last access: 2 September 2015), 2014c.

Saito, K., Miyazaki, S., Mori, J., Ise, T., Arakida, H., Suzuki, R., Sato, A., Iijima, Y., Yabuki, H., Iijima, Y., Sueyoshi, T., Hajima, T., Sato, H., Yamazaki, T., and Sugimoto, A.: GTMIP meteorological driving dataset for the GRENE-TEA observation sites (20-year detrended), 1.00, Arctic Data archive System (ADS), Japan, available at: https://ads.nipr.ac.jp/dataset/A20150205-001 (last access: 2 September 2015), 2015.

Sasai, T., Saigusa, N., Nasahara, K. N., Ito, A., Hashimoto, H., Nemani, R. R., Hirata, R., Ichii, K., Takagi, K., Saitoh, T. M., Ohta, T., Murakami, K., Yamaguchi, Y., and Oikawa, T.: Satellitedriven estimation of terrestrial carbon flux over Far East Asia with 1-km grid resolution, Remote Sens. Environ., 115, 17581771, doi:10.1016/j.rse.2011.03.007., 2011.

Sato, A., Kubota, H., Matsuda, M., and Sugiura, K.: Seasonal variation of heat exchange in the boreal forest of Finnish Lapland, Second Wadati Conference, on Global Change and the Polar Climate, extended abstracts, 228-230, 2001.

Schwalm, C. R., Williams, C. A., Schaefer, K., Anderson, R., Arain, M. A., Baker, I., Barr, A., Black, T. A., Chen, G., Chen, J. M., Ciais, P., Davis, K. J., Desai, A., Dietze, M., Dragoni, D., Fischer, M. L., Flanagan, L. B., Grant, R., Gu, L., Hollinger, D., Izaurralde, R. C., Kucharik, C., Lafleur, P., Law, B. E., Li, L., Li, Z., Liu, S., Lokupitiya, E., Luo, Y., Ma, S., Margolis, H., Matamala, R., McCaughey, H., Monson, R. K., Oechel, W. C., Peng, C., Poulter, B., Price, D. T., Riciutto, D. M., Riley, W., Sahoo, A. K., Sprintsin, M., Sun, J., Tian, H., Tonitto, C., Verbeeck, H., and Verma, S. B.: A model-data intercomparison of $\mathrm{CO}_{2}$ exchange across North America: Results from the North American Carbon Program site synthesis, J. Geophys. Res., 115, 2010.

Slater, A. G. and Lawrence, D. M.: Diagnosing present and future permafrost from climate models, J. Climate, 26, 5608-5623, doi:10.1175/JCLI-D-12-00341.1, 2013.

Sueyoshi, T., Saito, K., Miyazaki, S., Mori, J., Ise, T., Arakida, H., Suzuki, R., Sato, A., Iijima, Y., Yabuki, H., Ikawa, H., Ohta, T., Kotani, A., Hajima, T., Sato, H., Yamazaki, T., and Sugimoto, A.: The GRENE-TEA Model Intercomparison Project (GTMIP) stage 1 forcing dataset, Earth Syst. Sci. Data Discuss., 8, 703736, doi:10.5194/essdd-8-703-2015, 2015.

Takata, K.: Sensitivity of land surface processes to frozen soil permeability and surface water storage, Hydrol. Process., 16, 2155 2172, 2002.

Taylor, K. E., Stouffer, R. J., and Meehl, G. A.: An overview of CMIP5 and the experiment design, B. Am. Meteorol. Soc., 93, 485-498, 2012.

Todd-Brown, K. E. O., Randerson, J. T., Hopkins, F., Arora, V., Hajima, T., Jones, C., Shevliakova, E., Tjiputra, J., Volodin, E., Wu, T., Zhang, Q., and Allison, S. D.: Changes in soil organic carbon storage predicted by Earth system models during the 21 st century, Biogeosciences, 11, 2341-2356, doi:10.5194/bg-11-23412014, 2014.

Watanabe, K., Mizoguchi, M., Kiyosawa, H., and Kodama Y.: Properties and horizons of active layer soils in tundra at Tiksi, Siberia, Journal of Japan Society of Hydrology and Water Resources, 13, 9-16, 2000 (in Japanese with English abstract). 
Zaehle, S., Medlyn, B. E., De Kauwe, M. G., Walker, A. P., Dietze, M. C., Hickler, T., Luo, Y., Wang, Y.-P., El-Masri, B., Thornton, P., Jain, A., Wang, S., Warlind, D., Weng, E., Parton, W., Iversen, C. M., Gallet-Budynek, A., McCarthy, H., Finzi, A., Hanson, P. J., Prentice, I. C., Oren, R., and Norby, R. J.: Evaluation of 11 terrestrial carbon-nitrogen cycle models against observations from two temperate Free-Air $\mathrm{CO}_{2}$ Enrichment studies, New Phytol., 202, 803-822, doi:10.1111/nph.12697, 2014.
Zhang, T. J., Frauenfeld, O. W., Serreze, M. C., Etringer, A., Oelke, C., McCreight, J., Barry, R. G., Gilichinsky, D., Yang, D., Ye, H., Ling, F., and Chudinova, S.: Spatial and temporal variability in active layer thickness over the Russian Arctic drainage basin, J. Geophys. Res.-Atmos., 110, D14103, doi:10.1029/2004JD005474, 2005. 